\title{
Private Police Forces: Legal Powers and Limitations
}

\begin{abstract}
Although concern over the conduct and control of public police activities has provoked extensive discussion among legal commentators, ${ }^{1}$ the literature has largely ignored the role of private police. ${ }^{2}$ However, the rapid growth of the private police industry ${ }^{3}$ and the incursion of this industry into areas normally associated with public law enforcement $t^{4}$ raise important questions concerning the conduct and control of private police activities.

It is difficult to generalize about the private police industry. ${ }^{5}$ Diversification exists not only in the degree of training and professionalism
\end{abstract}

1 E.g., M. Banton, The Policeman in the Community (1964); A. Btack, The People and the Police (1968); P. Chevigny, Police Power: Police Abuses in New York Crty (1969); J. SKolnick, Justice Without Trial: LAW ENForgement in a Democratic Society (1966).

2 The only previous treatment of this subject in a legal periodical appears in Note, Regulation of Private Police, 40 S. CAL. L. REv. 540 (1967).

As used in this comment, the term "private police" refers to individuals or organizations who perform protective or investigative services for profit or in connection with other business, and who are not public employees engaged in the exercise of their official duties. This definition includes such groups as armored car agencies, private detective agencies, special patrol agencies, retail security guards, plant protection units, industrial security units, and campus security guards. The one significant group that does not fit this definition is the citizen volunteer patrol.

3 It has been estimated that $\$ 1.6$ billion was spent by the private sector for protective services in 1969. Creeping Capitalism, Forbes, Sept. 1, 1970, at 22 [hereinafter cited as FORBES]. "The security industry itself claims that two out of every three law enforcement officers in the nation are actually on private payrolls." Id. at 22.

1 Some private police agencies, structured along the lines of city police forces, have begun to provide patrol car and guard services to neighborhood groups and urban corporations. ForBes, supra note 3, at 22.

5 Much of the information set forth in this comment is based on interviews conducted in Chicago, Illinois, from September, 1970, to January, 1971. In many instances interviews were refused, and in other instances the interviewee declined to have his name or firm associated with his remarks. Very few interviews were conducted with small private investigators or private guards. Thus, the reader should note that the generalizations expressed concerning private police activities relate primarily to the larger agencies. For discussions of the small-scale operators, see REPORT OF THE NEW YORK STATE LECISLATIVE Commitree on Privacy of Communications and Licensure of Private Detectives 43-60 (1957) [hereinafter cited as Report on Private Detectives (1957)]; Report of THE NEw York State Legislative Commitiee on Privacy of Communications and Licensure of Prtvate Detectives 43-48 (1958) [hereinafter cited as Report on Prrvate Detectives (1958)]. 
of particular private policemen, ${ }^{8}$ but in the particular role for which they are employed.7 Although private police perform numerous functions, including the provision of armored car, patrol, and investigation services, they are used most extensively as uniformed guards in industrial and retail settings. ${ }^{8}$ Within these settings private police may serve a variety of purposes, including: the protection of property and persons from theft, fire, and other destructive events; the investigation and surveillance of employees to prevent pilferage and embezzlement; the maintenance of company order and the enforcement of rules and regulations; and the collection of information to influence business, legal, or personal decisions. ${ }^{8}$

These functions indicate that private police are oriented primarily toward prevention and protection, and not toward general law enforcement. ${ }^{10}$ The private interests that spawned the use of private police

6 "To an extent of which the public is perhaps unaware, licensed private detectives often engage men of scant ability and little stability. While generalization is impossible, we have been struck by the sporadic, short term, and poorly paid nature of much of the employment in this occupational group." REPORT on PRTVATE Detectives (1957), supra note 5, at 53. While this description is perhaps overly broad, the qualifications and training of private police do seem to reflect a relatively low level of responsibility. For example, the starting wage in Chicago, minois, for a security guard is $\$ 1.95$ per hour. A high rate of job turn-over also characterizes many private police activities. Most training is on-the-job; the typical security guard will begin work with, at most, an orientation lecture. In other areas, however, training seems to be quite extensive. See, e.g., R. SENG \& J. GILMour, BRINK's: The MONEx Movers 71 (1959). Investigators who have received top security clearance by the federal government are often trained in the full range of police techniques. The supervisory personnel of many private police agencies are well paid and well trained, and often have backgrounds in public law enforcement. Thus, no single label adequately fits the range of expertise prevalent in this field.

Variations in the size and sophistication of private police operations are equally great. There are three corporate giants in the field-Pinkerton's National Detective Agency, Inc., The William J. Burns International Detective Agency, Inc., and The Wackenhut Corporation. The largest, Pinkerton's, Inc., employs upwards of 25,000 field personnel. Interview with Edward Costells, Assistant Manager of the Chicago office, Pinkerton's National Detective Agency, Inc., in Chicago, Ill., Nov. 25, 1970. However, most holders of private detective licenses are either lone operators or small agencies which may employ fewer than fifteen people on a full time basis. REPORT ON PRIVATE Detectives (1958), supra note 5 , at 47 .

7 "Not only is there variety in the kinds of jobs done but also there is great specialization within well-known categories. One licensee is devoted to investigations in the perfume industry. Another serves exclusively a "clientele of railroads, steamship lines and common carriers.' One corporation is devoted to observing and reporting 'instances of taxi drivers carrying passengers without recording the fare on their meters.' "REPORT ON PRIVATE Detectives (1958), supra note 5, at 46.

8 Of the estimated 800,000 private police officers, approximately 500,000 are uniformed. FoRBEs, stupra note 3, at 22.

9 For a more comprehensive listing, see R. MOMboIsSE, INDUSTRIAL SECURITY FOR STRIKEs, RIOTS AND DISASTERS 52-54 (1968).

10 See, e.g., The Whliam J. Burns Int'l Detective Agency, Inc., Handbook for 
rarely seem to require, or tolerate, a wholesale displacement of public police forces. Thus, to avoid possible adverse public relations and potential tort liability, security guards are typically instructed to utilize public police whenever possible in matters touching the public domain, particularly arrests and searches. ${ }^{11}$ In some situations, however, private police must exercise powers analogous to those of their public counterparts. ${ }^{12}$ Retail security guards, for example, regularly arrest, search, interrogate, and seek criminal prosecution of suspected shoplifters. ${ }^{13}$ This comment explores the extent of these private police powers to arrest, search, and interrogate, and examines the adequacy of existing and potential controls on the exercise of these powers.

\section{General Iegal Framework}

Every citizen possesses certain common law and statutory powers of arrest, ${ }^{14}$ search and seizure,,$^{15}$ and self-defense. ${ }^{16}$ The private policeman enjoys these powers no less than any other individual. The question remains, however, whether private police are authorized to exercise powers greater than those granted to citizens generally. Although thirty-three states and the District of Columbia require licenses for cer-

GUARDS (1962) [hereinafter cited as BuRNS HANDBOOK]. "The protection of a plant by a guard unit is primarily preventive." Id. at 8 (emphasis in original).

11 "Whenever possible, have a law enforcement officer make the arrest, but if no law enforcement officer is available and an arrest is necessary, make sure that the law enforcement authorities are contacted immediately." Id. at 16.

12 Some agencies provide private police services which parallel or supplant public police forces. See note 4 supra. The parallel to public police forces is most clearly seen in campus security forces. As indicated in text at note 27 infra, many campus security police enjoy full police officer powers while engaged in the performance of their duties. These duties often include full scale patrolling of both private and public grounds. Where public police are allocated on the basis of crime rate, and to the extent campus security police are effective, the result may be that the campus security forces supplant the public police within a limited geographical area.

The desire to prevent and deter destructive acts may also invite a direct involvement in law enforcement and the criminal process: "Some advocate criminal prosecution for all thefts, but most [employers of industrial police] prosecute only the big ones. Nevertheless, all agree that occasional prosecution is a good deterrent to future crime." $R$. Momborsse, supra note 9, at 409. The decision to prosecute may also be influenced by other factors. In retail security these include the amount of the theft, the attitude of the shoplifter, and the degree of recidivism. Interview with a Director of Retail Security, in Chicago, Ill., Jan. 6, 1971 (name withheld by request).

13 See note 12 supra.

14 See text at notes $34-45$ infra.

15 See text at notes 69-76 infra.

16 See generally RESTATEMENT (SECOND) OF TORTS §§ 63-75; 1 F. HARPER \& F. JAMES, THE LAW OF TORTS $\S 3.11$ (1956). The citizen also possesses certain other related rights concerning defense of third parties, defense of unlawful intrusion upon property, and defending dispossession of real and personal property. Id. \$§ 3.12-.16. 
tain private police activities, ${ }^{17}$ these licenses generally confer no additional powers. ${ }^{18}$ At most the licensing statutes merely regulate the qualifications of licensees ${ }^{19}$ and their employees, ${ }^{20}$ and in some cases impose restrictions on the conduct of certain private police activities. ${ }^{21} \mathrm{How}-$

17 E.g., Cal. Bus. \& Prof. Code $\$ \S 7500-83$ (as amended, Supp. 1970); Del. Code ANN. tit. 24, §§ 1301-21 (Supp. 1968); ILI. ANN. STaT. ch. 38, §§ 201-1 to 201-51 (Smith-Hurd 1964); N.Y. GEN. Bus. LAW \$§ 70 to 89-a.

In addition, some municipalities require adherence to their own licensing provisions. E.g., Los ANgeles, CaL. Code $\S 21.117$ (1946). In other cases, the state statute authorizes certain classes of municipalities to regulate and license private detectives. E.g., Mo. ANN. STAT. $\S \S 73.110(17), 75.110(18), 84.340,84.720$ (1952). However, some state licensing statutes prohibit further licensing by any political subdivision of the state. E.g., Mrch. STAT. ANN. $\S 18.185(5)$ (Supp. 1970).

The coverage and exemptions of these statutes vary considerably. Most of the states require licensing of both private detectives and private patrolmen, although occasionally the statutes are broader, and may include, for example, a "repossessor," NEv. REv. STat. $\S 648.015$ (1967), or a polygraph operator, MAss. ANN. LAws ch. 147, § 22(1) (1965). Typical exemptions include officers of federal, state, and local governments, deputies and special police while on duty, insurance adjusters, practicing attorneys, and any person employed exclusively in connection with the affairs of his employer. The exemption for private police employed exclusively in connection with the affairs of their employers effectively excludes from coverage a majority of retail and industrial guards. E.g., N.C. GEN. STAT. $\S 66-49.2(2)$ (d) (1965); PA. STAT. ANN. tit. 22, § 25 (1955). This exemption has been explained in terms of “... [t] employer's self-advantage in selecting trustworthy employees and in supervising their work. . . " REPORT on PrIvate Detectives (1957), supra note 5, at 46. On the licensing statutes see generally $i d$. at 101-17 (statutes as of 1957).

18 See, e.g., License of Niehoff, 9 Pa. D. \& C.2d 410, 48 Berks County L.J. 286 (1956); Doherty v. Lester, 4 Misc. 2d 741, 159 N.Y.S.2d 219 (1957). But cf. Frank v. Wabash R.R., 295 S.W.2d 16 (Mo. 1956).

Occasionally the statutes grant some limited power, such as the right to carry a nightstick, Mich. StaT. ANN. § 18.185(19)(4) (Supp. 1970), or a non-concealed deadly weapon, N.M. STAT. ANN. § 67-33-44 (Supp. 1969). On the other hand, some of the statutes specifically deny certain powers, such as entering on private property without consent, N.M. STAT. ANN. \& 67-33-25(F) (Supp. 1969), or inducing a criminal confession by coercion or reward, Colo. Rev. Stat. ANN. § 44-I-10 (1963).

10 Among the most common qualifications are general provisions as to "honesty, competency, integrity and trustworthiness," a clean criminal record with respect to felonies and other specified crimes, and some prior law enforcement experience. E.g., N.Y. GEN. Bus. LAW § 72(1); PA. STAT. ANN. tit. 22, § 14(a) (1955). Sometimes the applicant must pass a written examination. E.g., ILl. ANN. Stat. ch. 38, § 201-6A(g) (Smith-Hurd 1964). Character references may also be required. E.g., N.C. GEN. STAT. § 66-49.3(b)(5) (1965). However, training requirements are rare. But see Mrch. STAT. ANN. § 18.185(31) (Supp. 1970); Vr. Stat. ANN. tit. 32, § 9507(5) (Supp. 1970).

20 Persons employed by a licensce are often required to register with the licensing authority, which usually entails submitting fingerprints and a photograph to the licensing authority. E.g., IlL. ANN. STAT. ch. 38, \$ 201-10b (Smith-Hurd 1964). See generally REPORT on Private Detectives (1957), supra note 5, at 52-53.

21 The principal restriction is the furnishing of a bond by the licensee to assure "the faithful and honest conduct of ... business by the applicant." The bond is usually available to "any person injured by the violation of any of the provisions of [the licensing statute], or by the willful, malicious and wrongful act of the principal or employe." PA. STAT. ANN. tit. 22, § 16(a) (1955). See also Myles v. Meinecke, 82 Ohio App. 126, 78 N.E.2d 917 (1948). The bonds may range anywhere from $\$ 1,000$ to $\$ 25,000$, although most average $\$ 5,000$ or less for individuals and $\$ 10,000$ or less for agencies. 
ever, in addition to licensing, some states and municipalities deputize, or "commission," private watchmen and guards. ${ }^{22}$ Typically, the commission vests the recipient with some or all of the powers of a public police officer during such hours and upon such premises as the commission may prescribe. ${ }^{23}$ In turn, the commission may require the recipient to adhere to the rules, regulations, and practices of the local police department. ${ }^{24} \mathrm{~A}$ commission, unlike a license, is not a prerequisite to engage in private police activities, and comparatively few private police appear to operate under a commission..$^{25}$ Finally, some states grant special powers, generally concerning arrest and search, to private police who are employed in connection with the affairs of certain categories of employers. Railroad detectives, ${ }^{26}$ campus security officers, ${ }^{27}$ and retail security guards ${ }^{28}$ are often granted such additional powers. In most states, however, the majority of private police seem to possess no powers beyond those of the ordinary citizen.

Abuses in the exercise of private police power are presently controlled by three factors: license revocation, criminal prosecution, and tort liability. The impact of license revocation appears minimal. In general, outside complainants initiate revocation proceedings. ${ }^{29}$ Except perhaps for the overcharged client, a complainant usually has little to

22 "It is a common practice in this country for private watchmen or guards to be vested with the powers of policemen, sheriffs or peace officers to protect the private property of their private employers." NLRB v. Jones \& Laughlin Steel Corp., 331 U.S. 416, 429 (1946). See also Williams v. United States, 341 U.S. 97, 98 (1951).

Some statutes permit the governor or some state agency to vest private police with special powers relative to the enforcement of particular state laws. E.g., ME. Rev. STAT. ANN. tit. 32, §§ 3801-02 (1965) (the governor may vest 50 private detectives with the arrest powers of a sheriff for the enforcement of laws relating to shoplifting, gambling, larceny, embezzlement, stolen goods, and certain misfeasance by state officers). Actually such statutes would appear to create a special state police force composed of private detectives. Commissioning, however, is aimed at protecting private interests.

23 E.g., Mo. ANN. Code art. 41, §§ 60-70 (1965); Mrrch. STAT. ANN. § 18.185(30) (Supp. 1970); N.C. GeN. STAT. §§ 74A-1, 74A-2 (1969); Chicaco, Ill., Code ch. 173 (1970); NEW YORK, N.Y., ADMINISTRATIVE CODE § 434a-7.0 (1963).

24 E.g., Houston, Tex., CODE § 30-74 (1958) ("Special officers shall at all times be subject to orders and instructions of ranking officers of the police department."). See also Frank v. Wabash R.R., 295 S.W.2d 16, 20, 21 (Mo. 1956).

25 Private police agencies usually have their men commissioned only upon the request of the client. The reasons for this appear to be twofold. First, the commission is usually limited to a specific address, and cannot be transferred when the guard is re-assigned. Second, many agency executives feel that the added powers conferred by a commission are not essential to the limited responsibilities of a security guard.

26 E.g., OKLA. STAT. ANN. tit. 66, § 183 (1964); W. VA. CODE ANN. § 61-3-41 (1966).

27 E.g., ARK. Stat. ANN. \& 7-112 to -120 (Supp. 1969) (state institutions); ILr. ANN. STat. ch. 144, § 28 (Smith-Hurd 1964) (University of Illinois); MAss. ANN. LAwS ch. 147, § 10G (Supp. 1969) (state and private institutions); TEX. REv. Crv. STAT. ANN. art. 5891A-1 (Supp. 1969) (private institutions).

28 D.C. CODE ANN. \$ 4-115 (1966); and see notes 44-45 infra.

29 See Report on Private Detectives (1957), supra note 5, at 54. 
gain from a revocation hearing, and where highly personal matters are involved, perhaps much to lose. ${ }^{30}$ As a result, complaints are seldom filed and revocation is rare. ${ }^{31}$ Thus, the legal burden of controlling private police conduct seems to rest on criminal and civil sanctions. Although it is unlikely that these remedies deter public police misconduct, certain factors suggest that they might be more effective against private police. ${ }^{32}$ The remaining sections of this comment examine the efficacy of these and other possible sanctions for controlling abuses of private police power in the areas of arrest, search, and interrogation.

\section{Arrest}

\section{A. The Power to Arrest}

An arrest is the apprehension of a criminal suspect for the purpose of bringing him before a public official to answer a criminal charge. ${ }^{33}$ Although private investigations and industrial security work may sometimes culminate in a private police arrest, the incidence of arrest is probably highest in the retail security context. ${ }^{34}$ Where time does not permit the security guard to summon public police, he must often arrest the suspect himself. Such arrests are necessarily without the protection of a warrant, and where the security guard is not deputized, the power to arrest normally depends on the common law and statutory authorization of citizen's arrest.

Under the common law, citizens and public police officers possessed apparently similar powers to make arrests without a warrant. ${ }^{35}$ Misdemeanant arrests were permitted only to preserve the public peace, and

30 "One must suspect that those who may have been pursued by private detectives are not eager thereafter to prolong the acquaintance by pressing complaints with the licensing authority." $I d$. at 41 .

31 "[C]omplaints against licensees [in New York State] average only a half dozen a year, and the disposition of them has been uniformly in favor of the licensee. Moreover, these complaints come from dissatisfied clients, rather than from harassed subjects of investigation." Id.

Where disciplinary action is administered, the action may amount to little more than a short term suspension of the license. For example, in Agency for Investigation and Detection, Inc. v. Dep't of State, 25 App. Div. 2d 738, 739, 169 N.Y.S.2d 168, 169 (1966), the licensee "acted in a shocking and most callous disregard of law and the rights of individuals" when he broke into a private dwelling and "pushed, shoved and committed acts amounting to assaults" upon the occupants. The court affirmed a two-month suspension of his license.

32 See text as notes 52-64 infra.

33 See generally Perkins, The Law of Arrest, 25 IowA L. REv. 201 (1940).

34 During one twelve-month period the member stores of New York City's Store's Mutual Protective Association apprehended nearly 10,000 suspected shoplifters. S. CuRTIS, MOdERN RETAIL Securry 779-82 (1960), as cited in Note, Regulation of Private Police, 40 S. CAL. L. REv. 540, 541 n.11 (1967).

35 See generally Perkins, strpra note 33; Wilgus, Arrest Without a Warrant, 22 Mrcr. L. REv. 541 (1924); Note, The Law of Citizen's Arrest, 65 ColuM. L. REv. 502 (1965). 
the law required an actual breach ${ }^{36}$ of the peace committed in the presence $^{37}$ of the arresting party. Felony arrests were permitted whenever a felony had actually been committed and there was reasonable cause to believe in the suspect's guilt. ${ }^{38}$ In addition, to supplement the arrest power, the arrestor was permitted to employ force if necessary, ${ }^{39}$ and to detain the arrestee for such time as was reasonably required to deliver him to an appropriate public official.40

Although many states have expanded the arrest powers of public police officers, ${ }^{41}$ the scope of permissible citizen's arrest, and the attendant powers of force and detention, have remained relatively constant.22 The breach of the peace requirement, however, has been eliminated in the context of most citizen misdemeanant arrests, ${ }^{43}$ and shoplifting statutes, ${ }^{44}$ which allow merchants to "detain" a suspect when reasonable

38 E.g., Commonwealth v. Wright, 158 Mass. 149, 158-59 (1893) (peace officer); Radloff v. National Food Stores, Inc., 20 Wis. 2d 224, 123 N.W.2d 570 (1963) (citizen). Because not all misdemeanors constitute a breach of the peace-petit larceny, for example-an arrest without a warrant may be unlawful even though the suspect is guilty.

37 E.g., Lynn v. Weaver, 251 Mich. 265, 231 N.W. 579 (1930) (peace officer); Carroll v. United States, 267 U.S. 132, 157 (1925) (citizen).

38 In some instances, however, a public police officer was permitted to arrest a suspected felon whenever he had reasonable cause to believe a felony had been committed. See Perkins, supra note 33, at 233-38.

39 See generally Note, Justification for the Use of Force in the Criminal Law, 18 STAN. L. REv. 566 (1961). A citizen is generally entitled to use whatever force is necessary to make the arrest. Id. at 569 . However, deadly force may be employed only to apprehend an escaping felon. See, e.g., People v. Lathrop, 49 Cal. App. 63, 192 P. 722 (1920). Some authorities have urged that the power to use deadly force in a felony arrest should be limited to public police officers. E.g., Model PENAL Code \& 3.07(2)(b)(ii), Comment at 58 (Tent. Draft No. 8, 1958). In any event, a citizen or private policeman is not authorized to use more force than a public police officer. Berryman v. Int'l Paper Co., 139 So. 2d 806 (La. App. 1962).

10 As a rule, the suspect must be taken without unnecessary delay before the appropriate authorities. E.g., Cline v. Tait, 116 Mont. 571, 155 P.2d 752 (1945) (peace officer); Singerman v. William J. Burns Int'l Detective Agency, Inc., 219 App. Div. 291, 219 N.Y.S. 724 (1927) (citizen). Moreover, “. . . imprisonment or detention beyond the reasonable time not only renders the imprisonment or detention illegal, but makes the entire transaction (including the arrest) a trespass ab initio." Great American Indemnity Co. v. Beverly, 150 F. Supp. 134, 140 (M.D. Ga. 1956).

41 E.g., Car. PEN. Code § 836; Il.. ANn. Stat. ch. 38, § 107-2(c) (Smith-Hurd 1970); N.Y. COde Crim. Proc. § 177; S.C. CODE ANN. §§ 17-251, -253 (1962). These statutes generally permit public police officers to arrest any suspect without a warrant whenever there is probable cause to believe in the suspect's guilt, or to believe that the suspect committed a crime in the officer's presence.

42 However, in Nebraska and Wyoming, citizens apparently enjoy greater powers of arrest in cases of petit larceny than do the public police officers. NEB. REv. STAT. $\$ 29-402$ (1943); WYo. STaT. ANN. \& 7-156 (1959).

13 E.g., Gal. Pen. Code § 837; Ill. ANN. Stat. ch. 38, § 107-3 (Smith-Hurd 1970); N.Y. CODE Crim. Proc. § 183; S.C. CODE ANN. §§ 17-25I, -252 (1962).

44 See generally Note, Survey and Analysis of Criminal and Tort Aspects of Shoplifting Statutes, 58 Mich. L. REV. 429 (1960). 
cause exists, ${ }^{45}$ have reduced to some extent the impact of the presence requirement.

The limited powers of citizen's arrest seem sufficient to permit private police to fulfill their protective functions. Although the principal limitation on the general power of citizen's arrest-the presence requirement for misdemeanant arrests-might have posed a serious restriction on retail security, since the guard is rarely present during the theft, the shoplifting statutes have largely eliminated this difficulty. In other private police contexts, either the arresting guard is present during the commission of the crime, or the crime constitutes a felony, and hence presence is not required. ${ }^{46}$

\section{B. Adequacy of Sanctions for Abuse of Arrest Power}

Perhaps because the arrest powers of private police are sufficiently broad in those areas where arrests are likely, private police agencies appear to stay well within the legal standards of arrest. ${ }^{47}$ Some agencies require adherence to even stricter arrest standards than the law requires. ${ }^{48}$ This restraint may be due in part to the sensitivity of these

45 The statutes normally provide that the detention shall be effected in a reasonable manner and for a reasonable length of time. They also specify the purpose of the detention. E.g., ALA. CODE tit. 14, § 334(1) (1959) (to effect recovery of the goods); ILL. ANN. STAT. ch. 38, § 10-3 (Smith-Hurd Supp. 1970) (to investigate ownership of the goods); Mass. Ann. Laws ch. 231, § 94-B (Supp. 1971) (to question the suspect); MinN. STat. AnN. $\$ \S 629.365,629.366$ (Supp. 1971) (to deliver the suspect to a peace officer); OHIO REv. CODE ANN. § 2935.041 (Baldwin 1964) (to cause an arrest to be made by a police officer). The statutes normally state that such detention shall not constitute an arrest, although the distinction apparently has no practical significance, other than to limit liability of the merchant. In addition, the statutes sometimes provide special defenses for the merchant or his agents in civil and criminal actions for false arrest, false imprisonment, and assault and battery.

46 In cases where private police investigations culminate in an arrest, some agencies indicate that their usual practice is to delay the arrest until they can apprehend the suspect in the act. Interview with Guido Mattei, Regional Manager of Burns Detective Agency, Inc., in Chicago, Ill., Jan. 8, 1971 [hereinafter cited as Burns Interview].

47 See note 46 supra.

48 See, e.g., BuRns HandBook, supra note 10, at 17:

A guard without police authority has only the power to arrest which the ordinary citizen has. That is, he may arrest a person under the following conditions: (a) The guard sees the person commit a felony. (b) The guard has reason to believe a felony was committed and that the person being arrested has committed it. (c) If a person is charged with a felony and the guard knows a warrant has been issued, he can arrest the offender without having the warrant in his possession.

These standards are, in one sense, more restrictive than the law of citizen's arrest, because they would allow only felony arrests. However, the Handbook is apparently mistaken when it would allow a felony arrest in the (b) situation above, where there is reason to believe a felony had been committed. Under the common law an actual commission of a felony was required, and only two states seem to have broadened citizen powers to include reasonable belief as to the commission of a felony. See ARK. STAT. ANN. $\S 43-404$ (1964); OHIO REv. CODE ANN. § 2935.04 (Baldwin 1964). 
agencies to potentially adverse public relations, since to further its business interests the private police industry must promote an image of restraint and professionalism. ${ }^{49}$ However, abuses of arrest power do occur, and in cases involving armed private police ${ }^{50}$ the injury has sometimes been substantial. ${ }^{51}$

The principal legal restraints on private police abuse of the arrest power are civil and criminal liability for false arrest, ${ }^{52}$ false imprisonment, ${ }^{53}$ and assault and battery. ${ }^{54}$ Although criminal sanctions are rarely invoked to punish such abuses, ${ }^{55}$ and the threat of prosecution is therefore unlikely to affect private police arrest conduct, the potential for civil liability appears to deter most illegal arrest practices.

It is generally agreed that civil liability is an ineffective deterrent to public police abuse. ${ }^{66}$ This may not be true, however, in the private

40 One impetus behind enactment of the private police licensing statutes was provided by private police themselves, principally the larger firms, who desired to give their industry a reputable image. Burns Interview, supra note 46 . And the desire continues:

This [New York State Committee] has heard suggestions from within the ranks of licensed private detectives for new educational requirements, for qualifying examinations, and for transfer of licensing authority from the Department of State to the Board of Regents-all for the purpose of establishing the private detective as a "professional man."

Report on Private Detectives (1957), supra note 5, at 50.

50 It is impossible to estimate what percentage of private police activities are conducted under arms. Agencies appear to arm their men only at the request of the client, or when the assignment is inherently dangerous. Apparently all armored car messengers carry arms. Retail security personnel, other than uniformed patrol guards, are not, in general, armed. The arming of industrial security guards seems to depend on the "... type of security interest involved, the number and kind of persons employed at the plant, and the character of the community or area in which the plant is located." R. Momborsse, supra note 9 , at 43 .

51 E.g., People v. Silver, 16 Cal. 2d 714, 108 P.2d 4 (1940) (night watchman killed a youth who had trespassed for the purpose of stealing gasoline); Myles v. Meineke, 82 Ohio App. 126, 78 N.E.2d 917 (1948) (plaintiff wrongfully shot by a private guard); Doherty v. Lester, 4 Misc. 2d 741, 159 N.Y.S.2d 219 (1957) (private detective shot and seriously wounded a nineteen-year-old suspect).

62 E.g., Martin v. Castner-Knott Dry Goods Co., 27 Tenn. App. 421, 181 S.W.2d 638 (1944); Peak v. W.T. Grant Co., 409 S.W.2d 58 (Mo. 1966).

53 E.g., Meinecke v. Skaggs, 123 Mont. 308, 213 P.2d 237 (1949); Great Atl. \& Pac. Tea Co. v. Smith, 281 Ky. 583, 136 S.W.2d 759 (1940).

54 E.g., Morgan v. Loyacomo, 190 Miss. 656, 1 So. $2 d 510$ (1941); Greenfield v. Colonial Stores, Inc., 110 Ga. App. 572, 139 S.E.2d 403 (1964).

55 Successful criminal prosecutions against public police officers are practically nonexistent: "It is absurd to suggest that any district attorney, or superior offcer, is going to take criminal action against one of his subordinates." White v. Towers, 37 Cal. 2d 727, 737, 235 P.2d 209, 215-16 (1951) (Carter, J., dissenting). Similarly, it appears that successful criminal prosecutions against private police are rare. Burns Interview, supra note 46.

${ }_{50}$ "The fact is, however, that there are several million illegal arrests and imprisonments in the United States each year, and that only a handful of damage suits are filed against policemen." Hall, Police and Law in a Democratic Society, 28 IND. L.J. 133, 152 (1953). See generally Foote, Tort Remedies for Police Violations of Individual Rights, 39 MiNN. L. REv. 493 (1955). 
police context. Although public and private policemen are often judgment proof, ${ }^{57}$ liability insurance carried by employers of private police and bonding requirements of most state licensing statutes may create a limited fund from which to satisfy claims against private police. ${ }^{58}$ Moreover, the potential pro-defendant bias in suits against public policemen $^{59}$ may play a lesser role in suits involving private police. Finally, while sovereign immunity often precludes suits against states and municipalities, ${ }^{60}$ the doctrine of respondeat superior generally enables plaintiffs to proceed against the employer of private police. ${ }^{61}$ Those few cases which take a narrow view of respondeat superior appear unsound. ${ }^{62}$

In practice, suits against private police are quite common ${ }^{63}$ and often

57 See Hall, supra note 56, at 153-54; Greenstone, Liability of Police Officers for Misuse of Their Weapons, 16 CLEv.-MAR. L. REv. 397 (1967). The low salary of an individual guard probably shields him from any substantial judgment. See note 6 supra.

68 Although these bonds are generally available to injured third parties, their effectiveness is limited both by their relatively small size, and by the numerous exemptions to the bonding requirements. See notes $17 \& 21$ supra. It is suggested that all private police who carry arms should furnish a bond, whether or not they are required to be licensed, and that the size of the bond should reflect the use of dangerous weapons. $C f$. Myles v. Meineke, 82 Ohio App. 126, 78 N.E.2d 917 (1948). Public police are sometimes required to furnish bonds. See Greenstone, supra note 57 , at 397 n.I.

69 "[A] current of sympathy for the police has begun to run through law-abiding segments of all communities in grateful recognition of the dangers and pressures to which these men daily expose themselves." Manos, Police Liability for False Arrest or Imprisonment, 16 Clev.-MAR. L. REv. 415, 427 (1967). Two members of this law-abiding segment have advocated civil immunity for all police activities performed in the course of duty, Jones \& Mathes, Toward a "Scope of Official Duty" Immunity for Police Officers in Damage Actions, 53 GEO. L.J. 889 (1965).

60 See generally Jaffe, Suits Against Governments and Officers: Sovereign Immunity, 77 HARv. L. REv. I (1963); Note, Municipal Immunity in Police Torts, 16 Gley.-Mar. L. Rev. 448 (1967). Although this doctrine appears to be undergoing steady erosion-see, e.g., Hargrove v. Town of Cocoa Beach, 96 So. $2 \mathrm{~d} 130$ (Fla. 1957)-it is notable that, under the Federal Tort Claims Act, recovery for false arrest, false imprisonment, assault, and battery is expressly excluded. 28 U.S.C. $\$ 2680(\mathrm{~h})$ (1964).

61 See cases cited at notes 52-54 supra. Moreover, at least one case has suggested that recovery may be permitted against the client of a private police agency, even though the service contract specifically provided that the agency would assume full responsibility for the private police operations. Komorowski v. Boston Store, 263 IIl. App. 88, 93-96 (1931).

62 Liability is normally imputed to the employer of a private policeman for those acts which occur within the scope of the employment. In determining this scope, courts sometimes test whether the activity was in furtherance of the employer's interests. See, e.g., Mackie v. Ambassador Hotel \& Inv. Corp., 123 Cal. App. 215, 11 P.2d 3 (1932). In Mackie the court held that, although the arrest furthered the employer's interests, the subsequent illegal detention did not, and hence the employer could not be held liable. The test should be expanded to include all acts performed in connection with the private policeman's employment-that is, all acts performed during duty hours and on duty premises-and should not depend on whether, in fact, an individual act benefited the employer.

03 One agency executive has estimated that in practically every case of unfriendly 
successful. And the profit orientation of private police agencies and their employers makes them particularly sensitive to large damage awards. ${ }^{64}$ Thus, in view of the moderation generally exercised by private police in arrest situations, existing civil and criminal sanctions seem adequate to deter abuse of the arrest power.

\section{SEARCH}

\section{A. The Power to Search}

A private policeman may desire to conduct a search ${ }^{65}$ for a variety of reasons. In the retail security context, the private guard may wish to search the person of an apprehended shoplifter to recover stolen property ${ }^{66}$ or to collect evidence for use either in a criminal prosecution or in defense of a civil suit for false arrest. Searches would also be useful in other areas of private police activity, particularly private investigation and industrial security. These could include search of a car or dwelling for pilfered goods or the use of electronic surveillance devices $^{67}$ to obtain information for use in making legal, business, or per-

contact between his operatives and the general public-such as ejecting an unruly patron at a sporting event-a civil suit ensued. Burns Interview, supra note 46. See also $\mathbf{R}$. Momboisse, supra note 9, at 414 .

B4 Although in many illegal arrests by private police the harm may be little more than dignitary, juries have often returned substantial verdicts. E.g., National Food Stores, Inc. v. Utley, 303 F.2d 284 (8th Cir. 1962) (\$10,000); Burke v. New York, N.H. \& H.R.R., 267 F.2d 894 (2d Cir. 1959) (\$2,250); Montgomery Ward \& Co. v. Medline, 104 F.2d 485 (4th Cir. 1939) ( $\$ 3,000)$; Gibson v. J.C. Penney Co., 165 Cal. App. 640, 331 P.2d 1057 $(1958) \ldots(\$ 5,000)$.

65 "Search" includes the following: (1) search of the person, including an area within his reach, Chimel v. California, 395 U.S. 752 (1969), his clothing and external patting thereof, Terry v. Ohio, 392 U.S. I (1968), and the surface and orifices of the body, including fingerprinting and taking of blood, Schmerber v. California, 384 U.S. 757 (1966);

(2) search of private property, including vehicles, Carroll v. United States, 267 U.S. 132 (1925); and (3) surveillance, including wiretapping and electronic eavesdropping, Katz v. United States, 389 U.S. 347 (1967), and the use of spies or informers, Osborn v. United States, 385 U.S. 323 (1966).

The literature on public police search and seizure is voluminous. Particularly useful is Model Code of Pre-Arraignment Procedure (Tent. Draft No. 8, 1970) [hereinafter cited as MCPP No. 3]. For a listing of authorities on the subject, see L. WeINREB, Criminat Process 764-68 (1969).

66 E.g., People v. Santiago, 53 Misc. 2d 264, 278 N.Y.S.2d 260 (Rockland County Ct. 1967).

67 Electronic surveillance or wiretapping is a form of search, and its use, like other forms of search, must conform to the strictures of the fourth amendment when engaged in by governmental authorities. Katz v. United States, 389 U.S. 347 (1967); Berger v. New York, 388 U.S. 41 (1967). See generally Kitch, Katz v. United States: The Limits of the Fourth Amendment, 1968 Sup. Cr. REv. 133; Kitch, The Supreme Court's Code of Criminal Procedure: 1968-1969 Edition, 1969 Sup. CT. REv. 155, 188-90; Note, From Private Places to Personal Privacy: A Post-Katz Study of Fourth Amendment Protection, 43 N.Y.U.L. REv. 968 (1968). 
sonal decisions. In the absence of consent, ${ }^{68}$ however, it appears that there is little legal authority for most forms of private search.

Surveillance by private parties, in the form of wiretapping, electronic eavesdropping, or interception of any oral or wire communication without consent, is almost entirely prohibited by Title III of the Omnibus Crime Control and Safe Streets Act. ${ }^{69}$ A number of states have also enacted legislation outlawing private wiretapping or electronic eavesdropping.70 Similarly, a private search of a building or vehicle without consent is generally prohibited, ${ }^{71}$ unless incident to an arrest. ${ }^{72}$

68 The law on consent search has developed primarily in the public police field. The courts generally require that waiver of fourth amendment rights be made voluntarily, and impose a rather strict burden of proof on the prosecution to show voluntariness. Johnson v. United States, 333 U.S. 10 (1948); Channel v. United States, 285 F.2d 217 (9th Cir. 1960). See generally MCPP No. 3, §§ 4.01-.03, Comments at 51-57. In the private police context the issue of voluntary consent might arise on a motion to suppress evidence if a statute provides for exclusion, see text at notes 98-100 infra, or as a defense to a suit for trespass or invasion of privacy. See generally W. ProssER, TORTS $\$ 18, \S 112$ at 850-51 (3d ed. 1964); RESTATEMENT (SECOND) OF TORTS \$\$ 167-84.

Moreover, a minority of federal courts have held that the principles announced in Miranda v. Arizona, 384 U.S. 436 (1966), which established strict standards for waiver of fifth and sixth amendment rights, require advising a suspect of his fourth amendment right to require a search warrant and waiver of that right by the suspect before a valid consent to a search may be obtained. United States v. Nikrasch, 367 F.2d 740 (7th Cir. 1966); United States v. Moderacki, 280 F. Supp. 633 (D. Del. 1968); contra, United States ex rel. Harris v. Hendricks, 423 F.2d 1096 (3d Cir. 1970). See generally Note, Consent Searches: A Reappraisal After Miranda v. Arizona, 67 Colum. L. REv. 130 (1967); Note, Constitutional Law-Miranda v. Arizona and the Fourth Amendment, 46 N.C.L. REv. 142 (1967). Analogously, private police might be required (though not on constitutional grounds) to advise a suspect of his right to refuse to allow a search. Failure to do so could be per se evidence of non-consent, either for the purpose of evidence exclusion or for imposition of tort liability on the private policeman for illegal search.

6918 U.S.C. \$§ 2510-11 (1964). Only oral communications "uttered by a person exhibiting an expectation that such communication is not subject to interception under circumstances justifying such expectation" fall within the purview of the Act. 18 U.S.C. $\S 2510(2)$ (1964). This language was intended to conform to the standards set out in Katz. S. REP. No. 1097, 90th Cong., 2d Sess. 2161-63, 2178 (1968) [hereinafter cited as SENare REPORT].

70 See Subcomm. on Administrative Practice and Procedure of the Senate Comm. on the Judiciary, 89th Cong., 2d Sess., Laws Relating to Wiretapping and Eavesdropping (Comm. Print 1966), for a listing of state statutes in effect in 1966. In contrast to the federal statute, some of the state statutes enforce blanket prohibitions on all unconsentedto eavesdropping. E.g., CAL. PEN. Code ANN. § 653i (1961); InL. ANN. Star. ch. 38, §§ 14-1 -2 (Smith-Hurd 1970). See also AmErican Bar Ass'N, Project on Minimum Standards for Criminal Justice, Electronic Surveillance (Tent. Draft, 1968).

71 The only conceivable support for a nonconsensual private search of a building or vehicle is an old common law property right, which granted the owner of personal property or his agent the right to enter upon the land of one who had wrongfully taken such property and return it to his own possession. The right has also seen some use in the shoplifting context. However, reasonable mistake as to the culprit or presence of stolen property was usually no defense to a later suit in trespass brought by the victim of the search. W. Prosser, supra note 68, at $\S 22$, pp. 119-20; Restatement (Second) of 
Search of a person by a private citizen appears to be limited to search incident to a lawful arrest or detention, though much of the authority for this right is ambiguous. Statutes in at least nine states allow any person making an arrest to seize weapons "about the person" of the arrested party and to deliver them to a magistrate. ${ }^{73}$ Two states authorize a personal search and seizure not only of offensive weapons, but of incriminating articles "about the person."74 Shoplifting statutes generally do not authorize a search of a suspect. ${ }^{75}$ The common law authority for a private search is sparse and inconclusive. ${ }^{76}$

In view of the dearth of authority on search incident to a lawful private arrest, some discussion of the issues involved seems appropriate. As a general consideration, since the public police are intended to be society's primary law enforcers, the limitations on public police search should set the upper boundaries of allowable search by private police. ${ }^{77}$ The perimeters of permissible public police search are, of course, established by the fourth amendment. ${ }^{78}$

TORTS $\$$ 100-06, and comment $d$ at 175; S.H. Kress \& Co. v. Musgrove, 153 Va. 348, 149 S.E. 453 (1929). The right has apparently fallen into desuetude. MCPP No. 3, supra note 65 , at 27 .

72 See text at notes 81-84 infra. Given the conclusion that private parties should have a limited right to search a person incident to an arrest, particularly for self-defense, there may be occasions when a cursory search of an area within the immediate reach of the arrestee would be equally necessary to fulfill that purpose; for example, when the arrestee is in a car. Chimel recognized this in the public police context. 395 U.S. at 763; and see MCPP No. 3, supra note 65, at 36-37.

73 Ariz. Rev. Stat. AnN. § 13-1415 (1956); Cat. Pen. Code Ann. § 846 (1961); Hawail REv. LAWS § 708-8 (1968); IDAHO CODE ANN. § $19-613$ (1948); IOWA CODE ANN. § 755.12 (1950); NEv. REv. STAT. § 171.146 (1969); N.D. CENT. CODE ANN. § 29.06-24 (1960); OKLA. STAT. ANN. tit. 22, § 206 (1969); S.D. CoMP. LAWs ANN. § 23-22-17 (1967).

74 Mich. Stat. ANN. \$ 28.884 (1954); Del. Code ANN. tit. 11, § 2303 (Supp. 1968). Both here and in note 73 supra, the statutes speak in terms of "about the person," which might easily be read to allow a search of both the person and the area within his reach. See note 72 supra. See also TEx. Code CRIM. Proc. ANN. § 18-22 (1966), which has received rather varied interpretation by the Texas courts. It seems fairly clear that search thereunder must be incident to a lawful arrest. Davis v. State, 113 Tex. Crim. 421, 21 S.W.2d 509 (1929).

75 Texas appears to be the only exception. Tex. PeN. Code ANN. art. 1436e(2) (Supp. 1970). See generally Comment, Survey and Analysis of Tort and Criminal Aspects of Shoplifting Statutes, 58 Mrch. L. REv. 429, 447-49 (1960).

76 One jurisdiction apparently grants the right, People v. Santiago, 53 Misc. 2d 264, 278 N.Y.S.2d 260 (Rockland County Ct. 1967); People v. Williams, 53 Misc. 2d 1086, 281 N.Y.S.2d 251 (Syracuse City Ct. 1967), while another limits search to that authorized by its search statute, People v. Martin, 225 Cal. App. 2d 91, 36 Cal. Rptr. 924 (1964). One case has totally disallowed such a right. Application of Fried, 68 F. Supp. 961 (S.D.N.Y. 1946). But cf. Agnello v. United States, 290 F. 671, 684 (2d Cir. 1923), rev'd in part, 269 U.S. 20 (1925); United States v. Viale, 312 F.2d 595 (2d Cir. 1963).

77 People v. Williams, 53 Misc. 2 d 1086, 281 N.Y.S.2d 251 (Syracuse City Ct. 1967); see Williams v. Williams, 8 Ohio Misc. 156, 221 N.E.2d 622 (C.P. 1966). But cf. note 42 supra.

78 "The right of the people to be secure in their persons, houses, papers, and effects, 
The right of public police to conduct a warrantless personal search is governed in part by Ghimel $v$. California, ${ }^{79}$ which authorizes a postarrest search of a person and the area within his immediate control where the policeman fears use of a dangerous weapon by the arrestee or where he has reasonable cause to believe the search will turn up destructible or easily concealed evidence. ${ }^{80}$ Search incident to an investigative "stop" or detention is considered in Terry v. Ohio, ${ }^{81}$ which authorizes a "frisk" or external pat-down of clothing where the officer fears that he or others may be in danger. If the frisk reveals the presence of weapons, the officer may conduct a personal search to remove them.

When an articulable suspicion of danger exists, granting a private policeman or citizen the authority to search for the purpose of finding and seizing weapons of an arrestee, at least equivalent to the pat-down approved by Terry, seems to be a necessary concomitant of the power to arrest. ${ }^{82}$ Furthermore, since private police generally have no authority to make an investigative detention or "stop" short of an arrest, ${ }^{83}$ it is probably most sensible to grant a right of full personal search when weapon use is feared. The difficult question is whether to allow a nonconsensual search to recover property for return to the owner or for use as evidence. These proprietary and evidentiary concerns can usually be satisfied by simply arresting the suspect and leaving search to the public police. The argument that search of a suspect may enable the parties to settle the matter without further recourse to the public police, and thus avoid stigmatizing the suspect with an arrest record or criminal conviction, ignores the possibility of arranging a valid consent search. If the stolen property is easily destructible or concealable, however, and if there is a substantial likelihood that the thief will destroy or conceal it before the public police arrive, an emergency search by the guard may be justifiable. ${ }^{84}$ The right would be analogous to that granted by Chimel, but might carefully be hedged by placing a strict

against unreasonable searches and seizures, shall not be violated, and no Warrants shall issue, but upon probable cause, supported by Oath or affirmation, and particularly describing the place to be searched, and the persons or things to be seized." U.S. Consr. amend. IV.

79395 U.S. 752 (1969); see MCPP No. 3, §§ 3.01-.04, Comments.

80395 U.S. at 763 .

81392 U.S. 1 (1968).

82 The statutory materials directly support this proposition, supra note 73. If the private party does arrest, and fears injury from the arrestee, it is doubtful that reasonable civil or criminal penalties would deter search for weapons. On the other hand, imposition of such penalties would force a citizen to arrest at his peril, hardly an incentive for private law enforcement.

83 See note 45 supra.

84 People v. Williams, 53 Misc. 2d 1086, 1090, 281 N.Y.S.2d 251, 256 (Syracuse City Ct. 1967). 
burden of proof on the searcher to demonstrate an absolute necessity for the search.

\section{B. Adequacy of Sanctions for Abuse of Search Power}

In discussing both the adequacy of existing sanctions to control private police search and the need for additional controls, it is useful to distinguish search of the person incident to an arrest from surveillance and private property searches. In the area of search incident to an arrest, private police practice does not appear to exceed permissible limits. ${ }^{85}$ The retail security guard generally does not search at all, relying instead on detention of a suspect until the arrival of public police, who then handle recovery of the property. Agencies involved in other types of police work-armored car service, for example-usually search only when the presence of dangerous weapons is suspected. Search of a more substantial nature is left to the public police. ${ }^{86}$ This lack of abuse is due at least in part to a consideration discussed earlier-the desire to maintain good public relations with customers and clients. ${ }^{87}$ Furthermore, deferral to public police is generally a viable alternative to selfhelp in making a search incident to an arrest. Thus, it appears that the threat of civil liability for trespass or assault and battery ${ }^{88}$ may be an adequate deterrent to illegal private police conduct in this area. If particularly flagrant abuses arise, criminal sanctions for assault and battery are available.

In contrast to private police search incident to an arrest, the existing legal prohibitions on surveillance and private property search appear to have little impact on certain forms of private-police activity. For example, private investigators, utilized by both domestic and business interests, commonly conduct illegal searches of dwellings ${ }^{89}$ and engage

85 See BuRNs HANDBOor, supra note 10, at 16, 18: "Always try to avoid physical contact, including body search, when making an arrest. ... Searches [of the person] should be made only when necessary ...." Cf. People v. Trimarco, 41 Misc. 2d 775, 245 N.Y.S.2d 795 (Sup. Ct. 1963). This and the generalizations which follow are in part the conclusions reached from the interview-study of private police practice.

86 This is the pattern seen in industrial security, armored car service, and the investigative aspects of retail security. See $R$. MOMBorss, supra note 9, at 403-15.

87 See text at notes $47-49$ supra.

88 I F. HARPER \& F. JAMES, supta note 16, at §§ 3.1-3.5.

89 E.g., Sackler v. Sackler, 15 N.Y.2d 40, 44, 203 N.E.2d 481, 483, 255 N.Y.S.2d 83, 86 (1964) ("Proof of guilt collected in raids by private detectives has been . . . the basis for thousands of divorce decrees in our State."); Williams v. Williams, 8 Ohio Misc. 156, 221 N.E.2d 622 (C.P. 1966); REPORT ON Private Detectives (1957), supra note 5, at 41; Agency for Investigation and Detection, Inc. v. Dep't of State, 25 App. Div. 2d 738, 169 N.Y.S.2d 168 (1966); Bylin, Super Snooper, Wall Street Journal, Feb. 17, 1971, at 1, col. I [hereinafter cited as Wall Street Journal]. 
in illicit surveillance activities, ${ }^{, 0}$ primarily to obtain information for use in a civil action or to influence some private decision or venture. ${ }^{91}$

The 1968 Crime Control Act prescribes both civil and criminal penalties for violation of its surveillance provisions..$^{22}$ Most state statutes which outlaw similar conduct prescribe at least criminal penalties. ${ }^{93}$ In addition, general civil and criminal sanctions for trespass are available in cases of illegal property search, ${ }^{94}$ and civil sanctions for invasion of privacy exist to control illegal surveillance. ${ }^{95}$ Yet the industry practices make it quite clear that these penalties are often inadequate to deal with the problems. This failure may be due to a number of factors. Because of their often surreptitious nature, these forms of search may pass undetected. ${ }^{96}$ Moreover, since the search may often involve embarrassing or confidential subject matter, victims may be hesitant to complain. ${ }^{97}$ Finally, the information obtained through these forms of search usually cannot be obtained by alternative legal methods or by engaging public police aid.

However, the federal act ${ }^{98}$ and some of the state statutes ${ }^{98}$ outlawing electronic surveillance provide a further sanction-evidence secured by private parties in violation of the surveillance provisions may not be

90 See Commonwealth v. Murray, 423 Pa. 37, 223 A.2d 102 (1966); REPORT OF THE New York State Legislative Committe on Privacy of Communications and Licensure of Private Detectives 20-22 (1960); Report of the New York State Legislative CoMmittee on Privacy of Communications and Licensure of Private Detectives 19-33 (1956); Wall Street Journal, supra note 89; SENATE REPORT, supra note 69, at 2154.

91 See Report on Private Detectives (1957), supra note 5, at 57-58; 2 sources cited note 89 supra. Private police agencies concerned with retail and industrial security, who might use an illegal search to uncover evidence of employee misfeasance-see Wall Street Journal, supra note 89; R. MoмBorsse, supra note 9, at 403-15; People v. Johnson, 153 Cal. App. 2d 870, 315 P.2d 468 (1957)-usually denied engaging in such activity. This was not surprising, however, in view of the heavy penalties which often attend such conduct. See text at notes 92-95 infra.

9218 U.S.C. \& $2511(1)$ (1964) provides than an offender "shall be fined not more than $\$ 10,000$ or imprisoned not more than five years, or both." 18 U.S.C. $\$ 2520$ (1964) provides for civil recovery of actual damages, if more than a prescribed liquidated sum, and both punitive damages and litigation costs.

93 See sources at note 70 supra. And see ILL. ANN. Star. ch. 38, § 14-6 (Smith-Hurd 1964) providing for injunctive relief and both actual and punitive damages.

94 See 1 F. HARpER \& F. JAMES, supra note 16, at §§ 1.1-1.10 (1956).

95 W. Prosser, supta note 68 , at $\S 112$, p. 833.

96 See SENATE REPORT, supra note 69 , at 2156.

97 See RePORT ON PRIVATE Detectives (1957), supra note 5, at 41, 57-58.

9818 U.S.C. $\S 2515$ (Supp. V, 1965-69) provides for exclusion in "any court, grand jury, department, office, agency, regulatory body, legislative committee, or other authority of the United States, a State, or a political subdivision thereof . . . ." See Senare REPORT, supra note 9, at 2184-85.

90 E.g., Ill. ANN. Stat. ch. 38, § 14-5 (Smith-Hurd 1964); Nev. Rev. STat. \$ 200.680 (1969); N.Y. Civ. Prac. LAW § 4506; ORE. Rev. Stat. § 41.910 (1969); R.I. Gen. Laws ANN. \$11-35-13 (Supp. 1970). 
introduced at judicial proceedings. It would seem that a similar exclusionary rule should apply to the fruits of unauthorized property searches, ${ }^{100}$ since the dangers of abuse and the difficulties of control seem identical. Although such a rule would have little impact on invasions of privacy for the purpose of gathering information not to be used in judicial proceedings, the effect on searches used to gather evidence for divorce suits and other types of civil actions might be quite substantial. $^{101}$ The deterrent effect of exclusion at criminal trials is more difficult to assess, since private search is apparently rarely intended to gather evidence for use at criminal trials. ${ }^{102}$

While it is unclear, then, whether legislative enactment of a criminal exclusionary rule applicable to surveillance and property searches is necessary, ${ }^{103}$ it would seem that, even assuming state action, ${ }^{104}$ a judicial extension of the fourth amendment exclusionary rule to the fruits of illegal private search is unwarranted. ${ }^{105}$ The fourth amendment rule renders evidence inadmissible in a criminal proceeding if law enforcement officers obtained it as a result of an unconstitutional search. ${ }^{106}$ Burdeau v. McDowell, ${ }^{107}$ decided by the Supreme Court in 1921, held the rule inapplicable to private parties. The Court concluded that the fourth amendment was intended to limit only governmental action. While recent decisions have followed the reasoning of Burdeau, ${ }^{108}$

100 See Tex. Code Crim. Proc. ANn. art. 38.23 (1966) (exclusion at any criminal trial of evidence against an accused obtained by any person in violation of Texas law or the federal Constitution); Williams v. Williams, 8 Ohio Misc. 156, 221 N.E.2d 622 (C.P. 1966); Del Presto v. Del Presto, 92 N.J. Super. 305, 223 A.2d 217 (1966) (exclusion of evidence at a civil trial when illegally obtained by a private party); $c f$. Deiner v. Mid-American Coaches, Inc., 378 S.W.2d 509 (Mo. 1964).

101 Report on Private Detectives (1957), supra note 5, at 57-58.

102 But cf. Knoll Associates, Inc. v. Dixon, 232 F. Supp. 283 (S.D.N.Y. 1964), and discussion at note 12 supra.

103 See text at notes 110-19 infra.

104 See text at notes 156-68 infra.

105 Some comment in the literature has argued that the rule be applied to private police. Comment, Regulation of Private Police, 40 S. CaL. L. REv. 540, 546-49 (1967); Comment, Seizures by Private Parties: Exclusion in Criminal Cases, 19 STAN. L. REv. 608 (1967).

100 Mapp v. Ohio, 367 U.S. 643 (1961). The rule also extends to search by private parties where they act at the hire or under the direction of governmental officials. E.g., Knoll Associates, Inc. v. FTC, 397 F.2d 530 (7th Cir. 1968); Corngold v. United States, 367 F.2d 1 (9th Cir. 1966); Stapleton v. Superior Court, 70 Cal. 2d 97, 447 P.2d 967, 73 Cal. Rptr. 575 (1969); People v. Tarantino, 45 Cal. 2d 590, 290 P.2d 505 (1955).

107256 U.S. 465 (1921). The Court has not since re-examined its position, though certiorari was denied in People v. Radazzo, 220 Cal. App. 2d 768, 34 Cal. Rptr. 65 (1963), cert. denied, 377 U.S. 1000 (1964).

108 E.g., Wolf Low v. United States, 391 F.2d 61 (9th Cir. 1968); Barnes v. United States, 373 F.2d 517 (5th Cir. 1967); United States v. Goldberg, 330 F.2d 30 (3d Cir. 1964); People v. Trimarco, 41 Misc. 2d 775, 245 N.Y.S.2d 795 (Sup. Ct. 1963). 
some courts have limited the exclusionary rule to public police on the additional ground that the rule would not deter illegal private conduct. ${ }^{109}$

The exclusionary rule represents a constitutional judgment that the need to protect fourth amendment rights outweighs the need to use all available evidence of guilt in criminal prosecutions. The Supreme Court in Mapp v. Ohio ${ }^{110}$ indicated that such a judgment depends upon two related factual assumptions: (1) that the rule would deter police violation of the fourth amendment, ${ }^{111}$ and (2) that the rule was in fact the only effective deterrent. ${ }^{112}$ Even with respect to public police the validity of these assumptions is questionable. ${ }^{113}$ In addition, some suggested alternatives to the rule might be more effective. ${ }^{114}$ Furthermore, the rule deters only searches intended to obtain evidence for use in a criminal prosecution. Thus, one reason assigned for the possible ineffectiveness of the rule in the public police context is that many police activities are not conviction oriented. ${ }^{115}$

Private police agencies appear to be even less conviction oriented than the public police. They seem to be concerned primarily with protection of property and personnel and with investigation of internal company business. Even the private investigator is rarely concerned with criminal convictions; his activities, when judicial proceedings are involved at all, are directed toward obtaining evidence for civil actions. A civil exclusionary rule, therefore, would be a far more effective deterrent of illegal private police conduct than would an extension of the fourth amendment criminal exclusionary rule. ${ }^{116}$ Furthermore, at least in the context of search incident to arrest, the threat of extensive liability in tort and the economic pressure to maintain favorable public

109 E.g., People v. Radazzo, 220 Cal. App. 2d 768, 34 Cal. Rptr. 65 (1963), cert. denied, 377 U.S. 1000 (1964); People v. Botts, 250 Cal. App. 2d 478, 58 Cal. Rptr. 412 (1967). See also recent cases involving illegal foreign police search: Stonehill v. United States, 405 F.2d 738 (9th Cir. 1968); Brulay v. United States, 383 F.2d 345 (9th Cir. 1968); Commonwealth v. Wallace, 356 Mass. 92, 248 N.E.2d 246 (1969).

110376 U.S. 643 (1961).

111 Id. at 656.

112 Id. at 651-52; see Elkins v. United States, 364 U.S. 206, 220-21 (1960); People v. Cahan, 44 Cal. 2d 434, 445, 447, 282 P.2d 905, 911-12, 913 (1955). See generally Oaks, Studying the Exclusionary Rule in Search and Seiztre, 37 U. CHI. L. REv. 665, 668-72 (1970).

113 See generally Oaks, supra note 112. Also see Terry v. Ohio, 392 U.S. 1, 12-15 (1968).

114 Oaks, supra note 112, at 673-74.

115 The Court in Terry v. Ohio, 392 U.S. 1, 13 (1968), stated:

[T] $n$ some contexts the rule is ineffective as a deterrent. Street encounters between citizens and police officers are incredibly rich in diversity ..... Encounters are initiated by the police for a wide variety of reasons, some of which are wholly unrelated to a desire to prosecute for crime.

See also Lankford v. Gelston, 364 F.2d 197 (4th Cir. 1966).

116 See text at notes 101-02 supra. 
relations may well be effective deterrents to private police misconduct..17 Thus, neither Mapp assumption holds true for private police activity, ${ }^{118}$ and, even assuming state action, application of a constitutionally based exclusionary rule to private police search appears to be unwarranted as a matter of policy. ${ }^{119}$

\section{INTERROGATION}

The right lawfully to detain a suspect is a necessary prerequisite of effective interrogation; ${ }^{120}$ without a right to detain, the suspect may simply walk away, just as he might if asked an unpleasant question by a fellow citizen. While there is no express authorization of private police interrogation during detention of a suspect, ${ }^{121}$ such interrogation

117 See text at notes 85-88 supra.

118 Note that this conclusion would not follow if Mapp were extended as a civil exclusionary rule to private police search. This is essentially the mechanism employed by the courts in Williams v. Williams, 8 Ohio Misc. 156, 221 N.E.2d 622 (C.P. 1966), and Del Presto v. Del Presto, 92 N.J. Super. 305, 223 A.2d 217 (1966), to create judicially a civil exclusionary rule. See note 100 supra. The problem with these cases is that they are doctrinally unsound, however correct they may be from a policy standpoint. Not only do they extend Mapp to private activity, in direct opposition to the trend of the case law, notes 108-09 supra, but they extend Mapp to civil proceedings, though that decision has been otherwise extended no farther than to quasi-criminal actions. See One 1958 Plymouth Sedan v. Pennsylvania, 380 U.S. 693 (1965); Comment, The Applicability of the Exclusionary Rule to Civil Cases, 19 BAyLOR L. REv. 263 (1967). Clearly the best solution is legislative enactment of such a civil rule, exemplified by the existing statutes providing a limited civil exclusionary rule in the eavesdropping context. See notes 98 \& 99 supra.

119 A criminal exclusionary rule in the private police area would be justifiable if carefully drawn to include only those areas of conduct where it might have some deterrent effect, whether on public or private police:

[A] rigid and unthinking application of the exclusionary rule, in futile protest against practices which it can never be used effectively to control, may exact

a high toll in human injury and frustration of efforts to prevent crime.

Terry v. Ohio, 392 U.S. 1, 15 (1968). From this standpoint, the Texas statutory exclusionary rule, TEX. CODE CRIM. PROC. ANN. art 38.23 (1965), may be too broadly drawn. See note 100 supra. And see Oaks, supra note 112, at 754-57, which concludes that the rule may be unjustifiable even in the public police area.

120 Miranda v. Arizona, 384 U.S. 436 (1966), dealt with "the protection which must be given to the privilege against self-incrimination when the individual is first subjected to police interrogation while in custody at the station or otherwise deprived of his freedom of action in any significant way." 384 U.S. at 477 (emphasis added). The Court termed such questioning "custodial interrogation." The detention requirement has been emphasized by later decisions. See, e.g., Orozco v. Texas, 394 U.S. 324, 826-27 (1969); Mathis v. United States, 391 U.S. 1, 4-5 (1968). People v. Rodney P. (Anon.) 21 N.Y.2d 1, 233 N.E.2d 255, 286 N.Y.S.2d 255 (1967). Note also the shoplifting statutes, which often grant a right to detain "for questioning." E.g., Mass. ANN. Laws ch. 281 \& 94-B (Supp. 1971) and sources at notes 44 \& 45 supra.

121 Every citizen has "the liberty . . . to address questions to other persons, for ordinarily the person addressed has an equal right to ignore his interrogator and walk away. . . ." Terry v. Ohio, 392 U.S. 1, 32-33 (1968) (Harlan, J., concurring). When 
may be justified as a matter of policy. The detention following a shoplifting arrest presents the typical situation in which a private policeman may want to interrogate a suspect. ${ }^{122}$ The guard or his supervisor may wish either to persuade the suspect to settle the matter on friendly terms by returning the missing property, or to determine if the situation justifies summoning the public police. The supervisor may also wish to obtain a confession from the shoplifter for use in a criminal prosecution or as a defense to a later action for false arrest. However, none of these justifications, nor the right to detain the suspect, implies any authority to use coercive tactics to compel the suspect to answer questions during an interrogation. ${ }^{123}$

Private police generally do not abuse their right to interrogate. Typically, a shoplifting suspect is taken to the office of the security supervisor ${ }^{124}$ and questioned in the presence of the arresting guard. ${ }^{125}$ Often the suspect is informed of his right to remain silent and right to counsel. ${ }^{126}$ Since post-arrest detention is usually permitted for only a brief

questioning is incident to a detention, however, that liberty becomes less clear. In the public police context, Miranda allows questioning by police only if the suspect has readily assented (assuming counsel is not present).

122 E.g., State v. Valpredo, 75 Wash. 2d 368, 450 P.2d 979 (1969); People v. Williams, 53 Misc. 2d 1086, 281 N.Y.S.2d 251 (Syracuse City Ct. 1967); People v. Crabtree, 239 Cal. App. 2d 789, 49 Cal. Rptr. 285 (1966).

123 This is true in both the public and private police contexts. Compulsion by the public police in interrogating a suspect is strictly prohibited by the fifth amendment as read by Miranda (though exclusion at trial is the only penalty). See also Malloy v. Hogan, 378 U.S. 1 (1964). Specific criminal penalties are also often imposed on public police. E.g., TEx. PEN. CODE art. 1157 (1961). Similarly, private police are subject to criminal penalties as well as liability in tort. See note 128 infra. Authority to compel testimony exists only where a governmental agency can guarantee immunity from prosecution to the party from whom testimony is sought. See, e.g., $1 \mathrm{~K}$. Davis, Administrative LAW TREATiSe § 3.08 (1958); 8 J. Wigmore, Evidence §§ 2281-82 (McNaughton ed. 196I); Garrity v. New Jersey, 385 U.S. 493 (1967); cf. Spevack v. Klein, 385 U.S. 511 (1967).

124 See the guard manual cited in Peak v. W.T. Grant Co., 409 S.W.2d 58 (Mo. 1966) ("In stores in which office is within view of sales floor it is advisable to take shoplifter to stockroom, employees' restroom, or other place ... ."); and sources at note 122 supra.

125 State v. Valpredo, 75 Wash. 2d 368, 450 P.2d 979 (1969), is an example of the typical handling of a shoplifting case. And see State v. Masters, 154 N.W.2d 133 (Iowa 1967).

128 E.g., State v. Valpredo, 75 Wash. 2d 368, 450 P.2d 979 (1969). Private parties are not constitutionally required to give the Miranda warnings. See text at notes 131-34 infra. Nevertheless, a substantial sector of the industry requires its operatives to give the Miranda warnings at the inception of all arrests or detentions, often despite specific advice of counsel to the contrary. Interview with a Director of Retail Security, in Chicago, Ill., Jan. 6, I97I (name withheld by request). A variant on this pattern is that the agencies require the warnings to be given in localities where the district attorney has interpreted Miranda as applying equally to private and public law enforcement personnel. Interview with a Director of Retail Security, Chicago, Ill., Dec. 6, 1970 (name withheld by request). A leading authority in the field of retail security has written: 
period, ${ }^{127}$ there is less likelihood than in public police interrogations that coercive methods will be effective to extract a confession. Unreasonable extensions of the period of detention and use of force and threats are discouraged by previously discussed economic factors and by tort and criminal sanctions. ${ }^{128}$ Nevertheless, the question often arises whether particular confessions should be admissible in a criminal trial of the confessor-suspect.

Exclusion of an improperly obtained confession may be based on purely evidentiary grounds: a coerced or involuntary confession may be unreliable. ${ }^{129}$ This rule has shown considerable vitality in the private police context, ${ }^{130}$ although the recent trend in evidence law which favors the admission of all probative evidence ${ }^{131}$ may point toward a diminishing role for this rule in the future.

In the public police context, a much more pervasive exclusionary

I have discussed this problem with District Attorneys in six states ... and found every one of them supported the belief that the Supreme Court ruling [Miranda] is an interpretation of the rights of ALL citizens and therefore is directed just as much at so-called "private police" as at public law enforcement. ... [A]s a consultant to the National Crime Commission I have had opportunity to discuss this situation with men connected with the commission and they also can see no reason for assuming the Supreme Court guidelines do not apply equally to private and public law enforcement personnel.

Letter from S.J. Curtis, author of MODERN RETAIL SEcurity (1968), to Eric T. Lodge, Dec. 16, 1966, on file in the University of Southern California Law Library, excerpt reprinted in Comment, Regulation of Private Police, 40 S. CAL. L. REv. 540, 546 n.36 (1967). In any event, awareness of Miranda seems high among supervisors of private police organizations.

127 The rights of a guard or his employer to detain after an arrest or by detention under a shoplifting statute are strictly limited, typically to detention in "a reasonable manner and for a reasonable time." See note 45 supra. In retail security practice, the public police are usually called immediately after the detention or arrest. Interviews with Retail Security Directors, Chicago, Ill., Dec. 6, 1970, and Jan. 6, 1971 (names withheld by request).

128 An overlong detention subjects the arrestor to liability for false imprisonment. See note 40 supra. Use of threats or force is discouraged not only by standard criminal sanctions for assault, battery, and intimidation, but also by specific provisions in some jurisdictions prohibiting private coercion of confessions. E.g., NEv. REv. STAT. $\$ 199.460$ (1967); Colo. Rev. Stat. ANN. \& 44-1-10 (1963); ILL. ANN. Stat. ch. 38, \& 12-7 (SmithHurd 1964).

120 See $3 \mathrm{~J}$. WIGMORE, EVIDENCE $\$ \S 821-30$ (1940).

130 E.g., Mefford v. State, 235 Md. 497, 201 A.2d 824 (1964); State v. Christopher, 10 Ariz. App. 169, 457 P.2d 356 (1969); People v. Frank, 52 Misc. 2d 266, 275 N.Y.S.2d 570 (Sup. Ct. 1966). And see Comment, Confessions Obtained Through Interrogations Conducted by Private Persons, Investigators, and Security Agents, 4 WhLAmetre L.J. 262, 266-68 (1966). There are also statutory enactments of the rule. E.g., Minn. Star. ANn. § 634.03 (1947); N.Y. Code Crim. Proc. § 395; Tex. Code CrIm. Proc. § 38.21 (1966), $\S 38.22$ (Supp. 1970).

131 See, e.g., On Lee v. United States, 343 U.S. 747, 757 (1952); United States v. United Shoe Mach. Corp., 89 F. Supp. 349 (D. Mass. 1950); Weinstein, Probative Force of Hearsay, 46 IowA L. REv. 331 (1961). 
rule is applied. Under Miranda $v$. Arizona ${ }^{132}$ any incriminating or exculpatory statement obtained from a criminal suspect during a custodial interrogation ${ }^{133}$ is inadmissible at his trial, unless prior to his statement the suspect was effectively advised of and knowingly waived his fifth amendment right to remain silent and his sixth amendment right to counsel..$^{134}$

Post-Miranda decisions have limited the rule to interrogations by police, governmental officials, and private police commissioned under state or local law. ${ }^{135}$ Interrogations by non-commissioned private police generally have been distinguished on the factual assumption that private-party interrogations are without the inherent "potentiality for compulsion" which the Miranda Court found in the public police context. ${ }^{136}$ The courts adopting this assumption may have felt that an extension of Miranda to private police was unwarranted in view of the rarity of private police abuse and the inability of Miranda to deter practices not motivated by a desire to convict. ${ }^{137}$ Furthermore, a few courts

132384 U.S. 436 (1966). Recent commentary on the decision is extensive. See H.J. FrIENDLY, BENChMARKS 266-84 (1967); Kamisar, $A$ Dissent from the Miranda Dissents: Some Comments on the "New" Fifth Amendment and the Old "Voluntariness" Test, 65 Mich. L. Rev. 59 (1966). See generally the bibliography in L. WrinREB, Criminal Process 770-74 (1969).

133 See note 120 supra.

134384 U.S. at $444-45$. Dissatisfaction with Miranda, primarily because of its restrictive effect on law enforcement, see SENATE REPORT, supra note 69, at 2123-53, has led to a legislative attempt to overrule the decision. In 1968, as part of the Omnibus Crime Control and Safe Streets Act, Congress enacted 18 U.S.C. § 3501 (Supp. V, 1965-69) in an attempt to return to pre-Miranda admissibility law. See text at notes 138-40 infra. The courts have not yet confronted the conflict, but as to its possible outcome, see Burt, Miranda and Title II: A Morganatic Marriage, 1969 Sup. CT. REv. 81. Moreover, it appears that the Burger Court views the fifth amendment in a somewhat less indulgent light than did its predecessor. See Harris v. New York, 39 U.S.L.W. 4281 (U.S. Feb. 24, 1971), holding, 5-4, that a confession from a suspect obtained in violation of Miranda might be used against him at a later trial to impeach his credibility on the stand.

135 Pratt v. State, 9 Md. 220, 263 A.2d 247 (1970) (holding that a citizen acting under a special police commission was subject to the Miranda requirements; see Commonwealth v. Bordner, 432 Pa. 405, 247 A.2d 612 (1968) (interrogation of a boy by his mother held subject to the Miranda requirements when she was acting at the insistence and in the presence of a law enforcement officer). For other "private" parties who may be subject to Miranda requirements, see Procunier v. Atchley, 39 U.S.L.W. 4125 (U.S. Jan. 19, 1971); People v. Polk, 63 Cal. 2d 443, 406 P.2d 641, 47 Cal. Rptr. I (1965); People v. Frank, 52 Misc. 2d 266, 275 N.Y.S.2d 570 (Sup. Ct. 1966). See generally Annot., Custodial Interrogation-Miranda Rule, 31 A.L.R.3d 565 (1970).

130 E.g., Shaumberg v. State, 83 Nev. 372, 432 P.2d 500 (1967); State v. Christopher, 10 Ariz. App. 169, 457 P.2d 356 (1969); see cases compiled in Comment, Admissibility of Confessions or Admissions of Accused Obtained During Custodial Interrogation by Non-Police Personnel, 40 Miss. L.J. 139 (1968).

137 Courts have recognized this distinction in other fields. See the cases in note 109 supra dealing with the fourth amendment exclusionary rule. One of those cases, Com- 
suggest that private police interrogations are not protected by the fifth and sixth amendments since nongovernmental agencies are involved and no state action exists. ${ }^{138}$ This last distinction is perhaps the only persuasive argument in favor of limiting the operation of Miranda to public police; the former distinctions may well be unsound.

Prior to Miranda, the admissibility of confessions made to governmental officers was controlled by a "voluntariness" doctrine resting on the fourteenth amendment. ${ }^{139}$ If it appeared from the facts surrounding a confession that it had been coercively obtained, the confession was excluded at trial as violative of due process. This decisional law represented the response of the Supreme Court to a long history of public police abuse,,$^{140}$ and the black-letter standards of Miranda may be viewed as the culmination of the Court's efforts to control public police interrogation conduct. Moreover, the Miranda Court was probably responding to a tendency of the lower courts to condone conduct which the Court felt violated standards of procedural fairness. ${ }^{141}$ Thus, to a considerable extent, Mirand $a$ was designed to deter public police abuse. Given this view of the decision, an extension of Miranda to private police interrogations would seem, as a matter of policy, unnecessary. As demonstrated by the apparent rarity of private police abuse in this area, the threat of civil and criminal liability, the fear of declining business, and the possibility of confession exclusion under evidence law seem adequate to deter most private police abuses.

Deterrence of police abuse, however, may not have been the only rationale underlying the Miranda decision. ${ }^{142}$ The marked shift in pro-

monwealth v. Wallace, 356 Mass. 92, 248 N.E.2d 246 (1969), also recognized this distinction in the Miranda context. See discussion at note 142 infra.

138 See Evalt v. United States, 359 F.2d 534, 542 (9th Cir. 1966); People v. Frank, 52 Misc. 2d 266, 275 N.Y.S.2d 570 (Sup. Ct. 1966).

139 E.g., Greenwald v. Wisconsin, 390 U.S. 519 (1968); Rogers v. Richmond, 365 U.S. 534 (1961); Haynes v. Washington, 373 U.S. 503 (1963). See generally Paulsen, The Fourteenth Amendment and the Third Degree, 6 SrAN. L. REv. 411 (1954).

140384 U.S. at 445-49; see IV National Comm'N ON LAW OBSERVANCE AND ENForceMENT, REPORT ON LAWLESSNESS IN LAW ENFORCEMENT (1931) (Wichersham Comm'n Report); Booth, Confessions, and Methods Employed in Procuring Them, 4 S. GAL. L. REv. 83 (1930).

141 Friendly, The Fifth Amendment Tomorrow: The Case for Constitutional Change, 37 U. CINN. L. REv. 671, 710-1I (1968). See, e.g., Greenwald v. Wisconsin, 390 U.S. 519 (1968); Clewis v. Texas, 386 U.S. 707 (1967). Moreover, Judge Friendly cites a growing mistrust in the Court of police honesty. Friendly, supra, at 711. Sce also Kitch, The Supreme Court's Code of Criminal Procedure: 1968-1969 Edition, 1969 Sup. Cr. REv. 155, 159-60.

142 Contra, Oaks, supra note 112, at 671 ('deterrence was the 'single and distinct' purpose" of the Miranda decision); and see Commonwealth v. Wallace, 356 Mass. 92, 248 N.E.2d 246 (1969). In that case foreign police officials had obtained a statement of guilt from the defendant without properly warning him of his rights as required by 
cedural standards from a "voluntary" confession to one obtained only after a "knowing and intelligent waiver" of rights ${ }^{143}$ and the emphasis on protection of fifth amendment rights ${ }^{144}$ suggest that the Court in Miranda was concerned also with erecting new protections for individual constitutional rights.

This aspect of Miranda was emphasized by the Supreme Court of Galifornia in People v. Kelley, ${ }^{145}$ which reversed a state court conviction of a serviceman based, in part, on a confession secured by a military investigator without the proper Miranda warnings. Despite the legality of the confession under military law, ${ }^{146}$ and even though recognizing that the decision might not deter military police practices, the court held the confession inadmissible:

One of the important purposes of the [confession] rules ... was that it was necessary to deter improper police practices ... that might lead to involuntary confessions [citations omitted]. But it cannot be denied that the whole series of cases-Escobedo, ... Miranda, Johnson, .... and their numerous progeny-was fundamentally aimed at protecting the Fifth and Sixth Amendment rights of the accused, that is, to protect against self-incrimination and to protect the right to counsel. ${ }^{147}$

Miranda. The confession was subsequently introduced in evidence against the confessor in a state-side criminal proceeding. The Supreme Court of Massachusetts held that the confession was properly admitted since foreign police practice would not be affected or deterred by an extraterritorial extension of Miranda. On Wallace, see United States v. Nagelberg (2d Cir. Nov. 9, 1970). But cf. Bram v. United States, 168 U.S. 532 (1897).

143384 U.S. at 475.

144 "The Fifth Amendment privilege is so fundamental to our system of constitutional rule and the expedient of giving an adequate warning ... so simple, we will not pause to inquire in individual cases whether the defendant was aware of his rights without a warning being given." Id. at 468.

14566 Cal. 2d 232, 424 P.2d 947, 57 Cal. Rptr. 363 (1967). See also Bram v. United States, 168 U.S. 532 (1897); United States v. Miller, 261 F. Supp. 442 (D. Del. 1965).

140 The California Supreme Court might have assumed otherwise had the case come up on appeal after the decision in O'Callahan v. Parker, 395 U.S. 258 (1969), where the Supreme Court limited military court criminal jurisdiction to cases which were "service connected." Id. at 272. In any event, the confession in Kelley would be admissible before a military tribunal. Military law does not afford a pretrial right to counsel, nor is that right guaranteed to service personnel by the federal Constitution. 66 Cal. 2d at 248-49, 424 P.2d at 960, $57 \mathrm{Cal}$. Rptr. at 376.

147 Id. at 250, $424 \mathrm{P} .2 \mathrm{~d}$ at $961,57 \mathrm{Cal}$. Rptr. at 377. This conclusion finds support in People v. Varnum, 66 Cal. 2d 808, 427 P.2d 772, 59 Cal. Rptr. 108 (1967), appeal dismissed, 390 U.S. 529 (1968), where the California Supreme Court held that a criminal defendant could not object to use at his trial of a confession obtained from a third party by public police in violation of Miranda standards. The court recognized that the defendant would have had standing to object if the evidence sought to be introduced had been secured in violation of the fourth amendment, since the fourth amendment exclusionary rule was designed primarily to deter illegal police search. But the court rejected the defendant's argument that protection of the fifth amendment privilege afforded by Miranda required analogous treatment: 
Thus the Warren Court may have been concerned not only with unconstitutional police abuses encouraged by the privacy and conviction orientation of public police interrogations, but with the inherently coercive capacity of those interrogations, which jeopardized effective exercise of the fifth and sixth amendment rights of an ignorant or fearful suspect. ${ }^{148}$ The Miranda warnings may therefore have been intended, at least in part, to dispel this fear and ignorance.

The principal factual distinctions between private and public police interrogations seem to be the strictly limited period of permissible private police detention and the unofficial, or informal, character of the questioning. ${ }^{149}$ However, numerous post-Miranda decisions indicate that neither a short period of detention ${ }^{150}$ nor the absence of recognized official character ${ }^{151}$ is sufficient to dispel the taint of compulsion in a custodial interrogation. Moreover, these distinctions are largely negated by the similarities between public and private interrogations-both involve detention, privacy, the appearance of authority, and the availability to the interrogator of psychologically coercive methods of ques-

Non-coercive questioning is not in itself unlawful, however, and the Fifth and Sixth Amendment rights protected by . . . Miranda are violated only when evidence obtained without the required warnings and waiver is introduced against the person whose questioning produced the evidence.

66 Cal. 2d at 812, 427 P.2d at 775, 59 Cal. Rptr. at 111.

For other authorities suggesting that Miranda was intended to do more than deter police abuse, see Harris v. New York, 39 U.S.L.W. 4281, $4294-95$ (U.S. Feb. 24, 1971) (Brennan, J., dissenting); letter cited in note 126 supra; Note, Evidence Taken in Violation of the Fourth Amendment and Statements Taken in Violation of the Fifth Amendment Held Admissible in a Domestic Court When Secured by Foreign Police, 56 VA. L. REv. 335 (1970).

148 Judge Friendly characterizes this new protection of the fifth and sixth amendments as "a ground bass that resounds throughout the Miranda opinion." Friendly, supra note 141, at 711. His idea is that the Warren Court sought equal protection of the sixth amendment and the fifth amendment privilege "by advancing the point at which the privilege became applicable and surrounding the poor man with safeguards in the way of warning and counsel that would put him more nearly on a par with the rich man and the professional criminal." Id. at 711 .

149 The argument here is that the suspect is aware that he is dealing with private parties and hence feels less compelled to answer questions than if his interrogators were public police. Factors which might dispel this informal atmosphere would be the presence of uniformed guards, a clear statement of intention by the interrogator that criminal prosecution is likely, or the suspect's awareness that the public police are on the way, typically the case in the shoplifting context. On the uniform question see People v. Wright, 249 Cal. App. 2d 692, 694, 57 Cal. Rptr. 781, 782 n.l (1967).

150 E.g., Orozco v. Texas, 394 U.S. 324 (1969); United States v. Pierce, 397 F.2d 128 (4th Cir. 1968). See also Miranda v. Arizona, 384 U.S. 436, 469 (1966): "The circumstances surrounding in-custody interrogation can operate very quickly to overbear the will of [a suspect] ...."

151 See Mathis v. United States, 391 U.S. 1 (1968); Procunier v. Atchley, 39 U.S.L.W. 4125 (U.S. Jan. 19, 1971); People v. Arguello, 13 Cal. 2d 566, 407 P.2d 661, 47 Cal. Rptr. 485 (1965). 
tioning. ${ }^{152}$ All of these factors were relied upon in Miranda. ${ }^{153}$ These similarities suggest that a significantly coercive atmosphere exists in the context of many private police interrogations, and that suspects, unwarned of their rights, may waive them through fear or ignorance. Moreover, extension of Miranda to private police would probably have a definite impact on their practices, since private police interrogation, in contrast to search or arrest, may be relatively conviction oriented..$^{154}$ Thus, as a matter of policy, an extension of both the procedural safeguards and exclusionary sanction ${ }^{155}$ of Miranda to private police interrogations may well be warranted.

The extension of Miranda, however, depends upon one further consideration-whether private police interrogations constitute state action. ${ }^{150}$ One possible basis for finding state action concerns the issuance of commissions. ${ }^{157}$ This approach was adopted by the Supreme Court in Williams $v$. United States. ${ }^{158}$ The Lindsley Lumber Company had suffered numerous thefts and hired petitioner, who held a special police officer card from the City of Miami and operated a detective agency, to ascertain the identity of the thieves. In the course of his investiga-

152 See Miranda v. Arizona, 384 U.S. 436, 448-54 (1966), and sources cited therein. Id. at 448 n.8. See also F. Inbay \& J. Reid, Criminat Interrogations and Confessions 24-117 (1967). A point developed earlier, note 6 supra, and deserving of further notice here, is that private police often have an extensive background in public law enforcement, particularly at the supervisory level. Furthermore, under present industry practice, field interrogations are generally the province of these supervisors alone. Burns Interview, supra note 46; Interviews with Retail Security Directors, Chicago, Ill., Dec. 6, 1970, and Jan. 6, 1971. BURNs HaNDBooK, supra note 10, at 18: "[Guard] duties do not include investigating persons committing crimes, except to the extent that oral questioning may be necessary. . . ." It would appear, then, that private police interrogation is often conducted with a level of inquisitorial skill and experience analogous to that displayed in the conduct of public police interrogations.

153384 U.S. at $449-58$.

154 A desire to effect a peaceable return of stolen property without involving the public police would seem to be the only motive for an interrogation not involving a desire to obtain a confession for use in court. This is in marked contrast to a search or arrest, which clearly serve the aims of property protection aside from conviction goals. Furthermore, the industry practice of administering the Miranda warnings, supra note 126 , is highly suggestive of a conviction orientation in private police interrogations. In many localities, the prosecuting attorney will refuse to prosecute a suspect to whom the warnings had not been given at the time of arrest. This is the underlying reason for administration of the Miranda warnings by at least one large retail security agency. Interview with a Diṛector of Retail Security, in Chicago, IIl., Jan. 6, 1971 (name withheld by request).

155 It is unlikely that the courts would enforce administration of the Miranda warnings by liability in tort. This step has not been taken even in the public police context. See Allen v. Eicher, 295 F. Supp. 1184, 1185-86 (D. Md. 1969) (". . . Miranda does not per se make an interrogation which violates its precepts into an actionable tort").

150 See text and notes at notes 137 \& 138 supra.

157 See text at notes 22-25 supra.

158341 U.S. 97 (1951). 
tion, petitioner imprisoned, beat, and brutally coerced confessions from four suspects. The Court upheld petitioner's conviction under the Civil Rights Act of $1866,{ }^{159}$ finding that his acts were performed under "color" of state law. ${ }^{100}$ In a 1970 decision, a Maryland court extended the strictures of Miranda to commissioned private police. ${ }^{161}$ The court held that the commission and its attendant powers made the private guard ". . . a law enforcement officer within the contemplation of Miranda."102 Thus, there appears to be some authority for finding state action in the conduct of commissioned private policemen.

Similarly, there may be authority for finding state action in interrogations by private police who are licensed under state or local law. This rationale has been used already to include within the strictures of the fourteenth amendment the discriminatory practices of licensed commercial establishments which cater to the public. ${ }^{163}$ In such cases it was found that the "pervasive" regulation by the state warranted application of the fourteenth amendment. ${ }^{164}$ This rationale may be applicable also where the state licenses private individuals to perform specialized police activities.

The scope of state action in the private police context may not, however, be so limited. In Marsh v. Alabama, ${ }^{105}$ the Supreme Court held that when a state permits a private business to perform all the functions of a municipal corporation, the public activities of the business constitute state action. The routine participation of private police in certain areas of law enforcement may sometimes supplant the public police, ${ }^{160}$ and to this extent private police are performing a public function. It is also apparent that private police coordinate their activities with the public police, and while the suggestion of a loose partnership may be too strong, private police are at least aware that the fruits of their investigations may be desired by the public police. Thus, although private police perform only limited public functions, the rationale of Marsh suggests that when the state permits private police activities, it may endow these activities with state action.

Aside from the governmental character of these functions, there is

15018 U.S.C. § 242 (1964).

160341 U.S. at 99.

101 Pratt v. State, 9 Md. App. 220, 263 A.2d 247 (1970).

$102 I d$. at 249.

103 E.g., Irvis v. Scott, 318 F. Supp. 1246 (M.D. Pa. 1970). And see Garner v. Louisiana, 368 U.S. 157, 182.85 (1961) (Douglas, J., concurring); Lombard v. Lauisiana, 373 U.S. 267, $281-83$ (1963) (Douglas, J., concurring).

104 Seidenberg v. McSorleys' Old Ale House, Inc., 317 F. Supp. 593, 599 (S.D.N.Y. 1970).

105326 U.S. 501 (1946).

100 See notes 4 \& 12 supra. 
the additional factor that private police activities often affect the general public. In Amalgamated Food Employees Union Local 590 v. Logan Valley Plaza, Inc., ${ }^{167}$ which extended Marsh to protect peaceful picketing of a privately owned shopping center, the Supreme Court considered the state action element in commercial establishments which cater to the general public:

The more an owner, for his advantage, opens up his property for use by the public in general, the more do his rights become circumscribed by the statutory and constitutional rights of those who use it. ${ }^{168}$

Thus state action may be present in the activity of a security guard employed by a privately owned shopping center, or by any private organization which deals with the general public. This rationale suggests that whenever private police activity affects a relatively broad spectrum of the public, state action is present and hence the Miranda requirements may apply to some private police interrogations.

\section{CONCLUSION}

Private police enjoy extensive powers which enable them to perform functions analogous to public police activity. In the area of arrest these powers are clearly defined, and for the most part require little modification. The search and interrogation powers of private police are in some cases more ambiguous, and here legislative delineation may be appropriate. Whether additional sanctions should be placed on the exercise of these powers depends upon the nature and extent of private police abuses and the deterrent effect of existing sanctions. While certain parallels between private and public police at least suggest that similar sanctions should apply to both, this preliminary inquiry indicates that the motivations and incentives of private police differ from their public counterparts, and that blanket application of public police sanctions to private police appears unwarranted. However, courts and commentators alike should be sensitive to the possibility that the existing powers and controls of private police may require alteration.

167391 U.S. 308 (1968).

168 Id. at 325, quoting Marsh v. Alabama, 326 U.S. 501, 506 (1946). 